\title{
How to Manage Insomnia and Sleep Disorders of Cancer Patients?
}

\author{
Seockhoon Chung \\ Department of Psychiatry, Asan Medical Center, University of Ulsan College of Medicine, Seoul, Korea
}

\section{암 환자의 불면증과 수면장애, 어떻게 관리할 것인가?}

정석훈

울산대학교 의과대학 서울아산병원 정신건강의학교실

Received April 13, 2020

Revised May 26, 2020

Accepted June 16, 2020

Address for correspondence Seockhoon Chung, MD, PhD

Department of Psychiatry,

Asan Medical Center,

University of Ulsan

College of Medicine,

88 Olympic-ro 43 -gil,

Songpa-gu, Seoul 05505, Korea

Tel: $+82-2-3010-3411$

Fax: $+82-2-485-8381$

E-mail: schung@amc.seoul.kr
The prevalence of insomnia is high among cancer patients. However, insomnia tends to be perceived as less important problem by patients themselves as well as clinicians. In this article, cancer-specific precipitating and perpetuating factors for insomnia, development of cognitive-behavioral therapy for insomnia especially for cancer patients, and pharmacological treatment of insomnia for cancer patients will be discussed. And also, various primary sleep disorders including circadian rhythm sleep-wake disorder, sleep-related breathing disorder, restless legs syndrome, and narcolepsy or idiopathic hypersomnia will be explained in the context of cancer.

J Sleep Med 2020;17(1):11-18

Key Words: Cognitive-behavioral therapy, Cancer, Insomnia.

\section{서 론}

암은 개인에게 극심한 스트레스원이 되는 질환이다. 암이 의심되어 검사를 실시하고 결과를 듣기까지 기다리고, 진단 을 받고, 치료를 하는 긴 기간 동안 환자들은 극심한 불안감 과 우울감, 불면증 등의 심리적 증상을 호소하게 된다. 그중 암 환자의 불면증 및 수면장애의 임상적 중요성은 상대적으 로 간과된 측면이 있는데, 불면증 및 수면장애는 삶의 질을 저하시키는 매우 흔한 증상이기 때문에 임상가들이 불면증 의 평가 및 치료에 좀 더 관심을 가질 필요가 있다. 우울증의 경우 한때는 암 환자의 우울증은 당연한 것으로 여겨졌으나, 우울증에 대한 적절한 치료가 암 치료 순응도를 높여 생존율 을 증가시킨다는 연구 결과들이 나오면서 우울증을 적극적 으로 치료해야 한다는 인식이 늘어난 바 있다. ${ }^{2}$ 불면증 역시 적절히 치료되지 않아 만성화되면 우울증과 같은 정신건강 문제를 유발하고, ${ }^{3}$ 신체적으로도 다양한 건강상 문제를 유발

This is an Open Access article distributed under the terms of the Creative Commons Attribution Non-Commercial License (https://creativecommons.org/licenses/by-nc/4.0) which permits unrestricted non-commercial use, distribution, and reproduction in any medium, provided the original work is properly cited.
하기 때문에 암 환자의 불면증 혹은 수면장애를 적절히 치료 하려는 인식의 전환이 필요하다.

불면증의 원인 및 기저질환에 대한 감별 진단 없이 수면제 만 처방하다 보면, 수면제 효과가 줄어들면서 처방되는 용량 이 늘어나기도 한다. 따라서 불면증에 대한 기본적 병력 청취 와 불면증을 유발할 수 있는 스트레스 및 내과적, 정신과적, 신경과적 기저질환들에 대한 감별, 그리고 불면증의 양상으 로 나타나게 되는 다양한 수면장애에 대한 파악이 무엇보다 중요하다. 그럼에도 불구하고 수면 전문가들의 관심이 생각 보다 높지 않은 이유는, 암 환자를 주로 진료하는 전문의와 수면장애를 전문적으로 진료하는 수면 전문가 사이의 접점 이 그리 많지 않았기 때문이다. 고령화 사회로 접어들수록 암에 대한 사회적 관심은 점차로 늘어날 것이고, 암 생존자 에 대한 호스피스 완화 의료가 확대되면서 주요 증상 중 하 나인 불면증에 대한 의학적 관심이 증가할 것임은 분명하다. 따라서 수면 전문가의 입장에서 암 환자들의 불면증 및 수면 장애에 대한 진단 및 치료 전략을 수립해 나가는 것은 매우 중요한 일이라 생각한다. 이를 위해 저자는 암 환자를 위한 수면장애 클리닉을 개설하여 불면증 및 수면장애에 대한 특 
화된 치료를 제공해 오고 있다. 이번 종설에서는 암 환자들 이 흔히 겪는 불면증 및 수면장애에 대하여 수면 전문가의 관점에서 어떻게 접근하고 어떤 치료 전략을 수립할 수 있을 지에 대한 논의를 해 보고자 한다.

\section{본 론}

\section{불면증}

불면증은 보통 일시적으로 발생했다가 호전되기도 하지 만, 잠들기 어렵거나 중간에 자주 깨거나 일찍 깨는 등의 증 상이 3개월 이상 지속되는 만성 불면증으로 진행할 수도 있 다. ${ }^{4}$ 전체 암 환자에서의 불면증 유병률 조사는 조사 방법에 따라 차이가 있으나 대략 59 79\% 정도의 범위에서 보고되 고 있으며,5,6 거의 모든 연구 결과가 일반 인구에 비해 2배 이 상 높은 수준으로 보고되고 있다. 심평원 자료를 이용한 국 내 10 대암 환자의 연구에서, 불면증 유병률은 폐암에서 가장 높고 갑상선암에서 가장 낮아, 각 암종의 임상적 특성으로 인하여 불면증 유병률이 달라질 수 있음을 보고하였다.

암을 진단받고 치료하는 과정 중에는 규칙적인 생활습관 을 유지하기가 쉽지 않다. 수술이나 항암 치료 후 피로감을 느끼게 되면 낮에 자주 누워서 쉬게 되고, 그러다 보면 밤에 도 잠을 잘 자지 못한다. ${ }^{8}$ 잠을 잘 못 자는 경우 수면제는 매 우 효과적이고 신속한 해결법이기는 하나, 수면제 처방에 대 한 올바른 이해가 뒷받침되지 않으면 수면제 용량이 점점 증 가하거나 내성 및 남용 문제가 발생하기도 한다. ${ }^{9}$ 일반인에 서와 마찬가지로 암 환자에게서도 불면증에 대한 1차적 치 료로 인지행동치료를 적용하는 것이 적절하다. ${ }^{10}$ 임상에서 인지행동치료를 실시하는 것이 쉽지 않은 것은 사실이나, 수
면제를 처방하기 전에 올바른 수면 습관에 대한 교육을 먼저 시행하는 것은 불필요한 수면제 처방을 줄이기 위해 필수적 이다. 특히 암 환자들은 많은 약물들을 투약 중이고 전신 상 태도 좋지 않은 경우가 많기 때문에 비약물적 치료를 우선적 으로 시행하는 것이 바람직하다.

인지행동치료는 수면과 관련된 잘못된 생각과 부적응적 행동을 교정하는 것에 초점을 두는 치료로(Table 1), ${ }^{11} 1$ ) 수 면 위생에 대한 교육, 2) 자극 조절법, 3) 수면 제한법, 4) 이완 요법, 5) 인지치료 등으로 구성된다. ${ }^{12-14}$ 각각의 요소를 조합 하여 4 6회기 정도로 구성하고 각 회기당 40 60분 정도의 시간을 배정하는 것이 일반적이다. ${ }^{15}$

수면과 각성을 조절하는 기전을 일반적으로 two process model을 이용하여 설명하는데, 내재되어 있는 일주기리듬 (circadian rhythm, process C)과 각성 시간에 따라 수면 항 상성(homeostatic process, process S)이 상호작용하여 수면각성이 조절된다는 이론이다. ${ }^{16}$ 즉 잠이 오는 시기가 정해져 있는데(process C) 낮 동안 각성 상태를 지속적으로 유지하 면 저녁에 잠이 오게 된다(process S)는 의미이다. 암 환자들 에게는 이 두 가지 기전의 불균형이 자주 관찰된다. 항암치 료를 받다 보면 수면-각성리듬이 깨지게 되고, ${ }^{17}$ 이는 일주 기리듬을 반영하는 코티솔이나 멜라토닌의 불규칙적인 분비 를 통해서 파악할 수 있다. ${ }^{18}$ 특히 암 환자들은 피로감 때문 에 낮 동안에 활동량이 저하되고 이는 야간의 수면의 질 저 하와 직결된다. ${ }^{19}$

암 환자는 불면증 발생의 원인에 있어서도 일반인과는 차 이를 보이기에 암 환자에게 특화된 인지행동치료 기법의 개발 및 적용이 필요하다. 20,21 불면증의 만성화 과정을 보통 3-P 모 델로 설명하는데,22 이는 불면증에 취약한 소인적 요인(pre-

Table 1. Summary of cognitive-behavioral therapy for insomnia components

\begin{tabular}{|c|c|}
\hline Component & Treatment goal \\
\hline Sleep hygiene & $\begin{array}{l}\text { Eliminate habits that are counterproductive for sleep through education on general guidelines about health } \\
\text { behaviors and environmental factors that negatively impact sleep (e.g., reduce drinking alcohol, avoid } \\
\text { rigorous exercise close to bed time). }\end{array}$ \\
\hline Stimulus control & $\begin{array}{l}\text { Strengthening sleep cues (e.g., bed and bedroom) with sensations of sleepiness by limiting the amount of time } \\
\text { spent awake in bed. Patients are instructed to only go to bed when sleepy, use the bed only for sleep and } \\
\text { sexual activity, and leave the bed if unable to fall asleep for more than } 15 \text { to } 20 \text { minutes. }\end{array}$ \\
\hline Sleep restriction & $\begin{array}{l}\text { Restrict time in bed to improve sleep drive and consolidate sleep. By systematically reducing time in bed, } \\
\text { homeostatic pressure for sleep is increased, which in turn increases sleep consolidation. The goal of sleep } \\
\text { restriction is to reach sleep efficiency of higher than } 85 \% \text { and to avoid compensating for poor sleep. }\end{array}$ \\
\hline Relaxation techniques & $\begin{array}{l}\text { Reduce physiological arousal and decrease anxiety (e.g., engaging in deep breathing exercises, progressive } \\
\text { muscle relaxation, or autogenic training to reduce somatic tension or intrusive thoughts that interfere with } \\
\text { sleep). }\end{array}$ \\
\hline Cognitive therapy & $\begin{array}{l}\text { Address and correct maladaptive thoughts, beliefs, and expectations about sleep that interfere with sleep and } \\
\text { daytime functioning (e.g., misattributions of daytime impairments to poor sleep). }\end{array}$ \\
\hline
\end{tabular}

Adapted from Ong \& Suh. Sleep Med Res 2012;3:1-6, with permission of Oxford University Press ${ }^{11}$ 
disposing factor)을 갖고 있는 사람이 불면증을 유발할 만한 유발 요인(precipitating factor)이 있을 때 급성 불면증이 발생 하고, 수면과 관련된 과도한 불안감, 부적응적인 수면 습관 과 같은 지속 요인(perpetuating factor)에 의하여 불면증이 만성화된다는 이론이다. 암 환자에서는 암 진단과 치료 과정 에서 환자들이 겪게 되는 다양한 디스트레스, 증상, 부작용 등으로 인한 정신적, 신체적 변화가 불면증의 유발 요인과 지속 요인으로 작용할 수 있다(Table 2).

암 환자에게 수면제를 처방하기 전, 교정 가능한 유발 요인 (precipitating factor)에 대한 평가가 우선되어야 한다. 암 진 단 과정에서 받은 정서적인 충격으로 불안감 및 우울감, 그 리고 불면증이 흔히 발생한다. 또한 신체 증상, 수술과 입원, 항암요법, 방사선요법, 항호르몬요법 등의 부작용이 불면증 의 주된 유발 요인으로 작용하기도 한다. ${ }^{23}$ 심한 통증 때문에 불면증이 발생했다면 통증 조절이 우선되어야 하겠고, 유방 암 환자에게서 tamoxifen 등 항호르몬 요법 시 안면홍조나 야 간 발한 등이 발생하여 불면증이 생긴 경우라면 세로토닌 노 르에피네프린 재흡수 차단제(serotonin norepinephrine reuptake inhibitor, SNRI) 등의 항우울제나 gabapentin을 사용해

Table 2. The 3-P model for chronic insomnia among cancer patients ${ }^{20}$

\begin{tabular}{ll}
\hline Predisposing factor & Older age \\
& Female gender \\
& Family history \\
& Medical comorbidities \\
& Hyperarousability \\
& Psychological state \\
& Personality trait \\
Precipitating factor & Stress from cancer/treatment \\
& Psychiatric symptom (depression, anxiety) \\
& Cancer-related symptoms \\
& (pain, fatigue, hot flashes) \\
& Surgery \\
& Hospitalization \\
& Radiotherapy \\
& Chemotherapy \\
& Corticosteroids \\
& Certain medications \\
& Hormonal or biological therapy \\
& Cytokine production \\
Daytime naps & Excessive time in bed \\
Irregular sleep-wake schedule & Sleep interfering activities \\
& Unatching TV in bed) \\
& Faulty appraisal of sleep difficulty \\
&
\end{tabular}

볼 수 있다. ${ }^{24}$

\section{불면증 인지행동치료의 암 환자에의 적용}

인지행동치료는 불면증의 3-P 모델 중 마지막 요소인 지 속 요인에 대한 교정을 목표로 한다. 암 치료 과정 중 발생한 부적응적인 수면 습관들(자지도 않으면서 침대에서 많은 시 간을 보내는 것, 낮잠을 습관적으로 자는 것, 불규칙적인 수 면 패턴, 침대나 침실에서 취침 이외의 활동을 하는 것 등)과 역기능적인 생각(잠을 못 잘 것에 대한 지나친 두려움과 걱 정, 잠을 못 자면 다음 날 생활을 제대로 못할 것이라는 불안 감, 불면증으로 인해 건강이 악화될 것이라는 생각 등)이 생 기기 쉽기 때문에 이를 파악하고 해결하는 것에 중점을 둔다.

\section{수면 위생 교육의 암 환자에의 적용}

암 환자들은 암으로 인한 정신적 스트레스와 피로감 때문 에 낮잠을 자거나 평소보다 수면 시간을 늘리는 경우가 많은 데, ${ }^{25}$ 이는 불면증을 지속시키는 요인이 된다. ${ }^{5}$ 따라서 항암치 료 전부터 환자의 수면 습관을 파악하고, 치료 이후 발생할 부작용을 고려하여 수면 습관 교육을 실시할 필요가 있다. 규칙적인 운동을 하되 늦은 저녁 시간의 운동을 피하고, 단 기간의 운동보다는 꾸준한 운동이 수면의 질 향상에 도움이 된다. ${ }^{26}$ 피로감으로 인한 휴식이 필요하다면 늦은 오후나 저 녁에는 낮잠을 피하도록 해야 하고 취침 시간과 기상 시간을 일정하게 하도록 한다.

자극 조절법의 암 환자에의 적용

자극 조절법의 핵심은 잠자리에서는 잠만 자는 것이라는 점을 인식시키는 것이다. 따라서 잠이 오지 않으면 침실 밖 에서 생활을 하고 잠이 오면 침실로 들어가도록 권장한다. 암 환자들은 낮에 쉽게 피로감을 느끼는 경우가 많다 보니 낮 동안에 누워서 지내는 시간이 상대적으로 많다. 그러다 보면 낮 동안 주로 거실에서 생활하고, 밤에도 거실에서 잠 을 자는 경우가 많다. 또는 역으로 침실에 TV를 두고 낮에도 침실에서 생활할 수 있게 수면 환경을 변화시킨다. 이러한 행동은 잠자는 공간과 생활을 하는 공간의 경계를 무너뜨려 불면증을 악화시킨다. 따라서 잠자는 공간과 생활을 하는 공 간을 분리하기 위해, 낮에는 거실에서 생활을 하고 저녁에 잠을 잘 때에만 침실에 들어가도록 교육한다. 또한 야간에 잠이 오지 않으면 누워서 $\mathrm{TV}$ 를 시청하면서 잠을 청하는 경 우가 잦은데, 이 또한 잠자리와 잠을 자는 행위 간의 연결고 리를 약화시키기 때문에 TV는 반드시 거실에서 앉아서 시청 하는 것을 권한다. 잠들었다가 중간에 잠이 깼을 때 다시 잠 드는 것이 어려운 경우, 10 15분 정도 누워서 잠을 청해 보 
다가 정 잠이 오지 않으면 거실에 나와서 앉아 있다가 잠이 오면 다시 눕는 것을 권한다.

수면 제한법의 암 환자에의 적용

수면 제한법은 자지 않은 상태로 누워 있는 시간이 길어질 수록 수면의 효율이 저하되고 깊은 잠을 자기 어렵게 된다는 것에 기초한 치료법이다. 잠자리에 누워 있었던 모든 침상 시간(time in bed, TIB) 중 실제로 잠을 잔 시간(total sleep time)의 비율을 의미하는 수면 효율(sleep efficiency)이라는 지표는 수면 제한법에서 중요하게 사용된다. 저녁에 잠자리 에 들기 시작하여 아침에 잠자리에서 나올 때까지의 시간을 총 침상 시간(TIB)으로 평가하는데, 이 지표에는 낮 동안 누 워 있는 시간이 반영되지 못한다. 암 환자들은 누워서 하루 를 보내는 경우가 많으므로, 고전적인 방법으로 총 침상 시 간을 평가하면 환자의 실제 수면 효율보다 높게 평가될 수가 있다. 암 환자들이 하루 중 누워 있는 총 시간을 반드시 고려 해야 하기 때문에, 이를 보완하기 위해 저자는 하루 중 총 침 상 시간(total TIB during 24 hours, TIB/d)이라는 개념의 지 표를 제안한다(Table 3). ${ }^{27}$ 수면 효율이 저하되면 수면의 질 이 저하되기 때문에 낮 동안 누워 있는 시간을 줄이고 외부 활동을 하는 것이 좋다. 다만, 이를 위해서 암 환자의 피로감 을 감소시킬 수 있는 방안이 같이 고려되어야 한다. 빈혈과 같은 기저 내과적 문제를 교정하고, 운동이나 행동 교정 등을 시행해 볼 수 있으며, 증상에 따라서는 정신 자극제 또는 항 우울제를 시도해 볼 수 있다. ${ }^{28}$

Table 3. Sleep parameters for evaluating sleep structure

\begin{tabular}{lll}
\hline Abbreviation & \multicolumn{1}{c}{ Explanation } & \multicolumn{1}{c}{$\begin{array}{c}\text { Definition } \\
\text { (not absolute) }\end{array}$} \\
\hline SOL & Sleep onset latency & $20,30,45 \mathrm{~min}$ \\
TIB & Time in bed & $7 \mathrm{hr}: 11 \mathrm{pm}-6 \mathrm{am}$, \\
& & $12 \mathrm{am}-7 \mathrm{am}$ \\
TIB/d ${ }^{27}$ & Total time in bed during & $7-8 \mathrm{hrs}$ \\
& 24 hours & \\
TST & Total sleep time & $7-8 \mathrm{hrs}$ \\
SE & Sleep efficiency & $85 \%, 90 \%$ \\
WASO & Wake after sleep onset & $20,30,45 \mathrm{~min}$ \\
PTB ${ }^{29}$ & Duration from administration & $<30 \mathrm{~min}$ \\
& of pills to bedtime & \\
PTS $^{29}$ & Duration from administration & $<30 \mathrm{~min}$ \\
& of pills to sleep onset time & \\
PTW $^{29}$ & Duration from administration & $7-8 \mathrm{hrs}$ \\
& of pills to wake up time & \\
\hline
\end{tabular}

인지치료의 암 환자에의 적용

우리나라의 암 환자들에게 흔히 관찰되는 잠에 대한 역기 능적 생각이 있는데, "10시에서 2시 사이에 잠을 잘 자지 못 하면 면역력이 떨어진다.”와 “잠을 잘 자지 못하면 암이 재발 한다.”라는 믿음이다. ${ }^{30}$ 근거가 전혀 없는 것은 아니다. 전자 의 경우 멜라토닌이 면역계에 미치는 영향이라는 의학적 사 실에 근거하고 있으며, ${ }^{31}$ 후자의 경우 지나치게 짧거나 긴 수 면 시간과 암 발생률 또는 암 환자의 생존율과의 관련성에 근거한다. ${ }^{32}$ 하지만 암 환자들이 대중매체를 통해 이러한 정 보를 접하게 되면 불면증에 대해 과도하게 걱정을 하게 되 고, 이는 심한 불안과 두려움으로 이어져 역설적으로 잠을 더 자기 어렵게 만든다. 이에 따른 극도의 스트레스는 체내 의 코티솔 농도를 증가시키고 면역력을 저하시킨다. ${ }^{33}$ 암 환 자에게 인지치료를 시행할 때 중요한 지점은, 환자가 갖고 있는 생각이 일정 부분 사실이라 하더라도 불안이 증폭된다 면 오히려 불면증을 악화시키기 때문에, 그 사실에 대해 반 복적으로 생각하지 않는 것이 역설적으로 잠을 잘 자게 되는 것임을 이해시키는 것이다.

이완요법의 암 환자에의 적용

암 환자에 대한 이완요법의 효과는 잘 알려져 있다. 지나친 불안과 긴장은 불면증에 영향을 줄 뿐 아니라 통증이나 오심 등 신체 증상에 대한 민감도를 높인다. 이완요법은 환자의 통 증이나 피로감, 불면증을 감소시키는 데 도움이 되며, ${ }^{34}$ 불안 감을 감소시켜 통증 민감도와 불면증에 대한 과도한 걱정을 줄이는 데 효과적이다. 바이오피드백 장비를 이용하여 자율 신경계의 조절을 받는 불수의적 생리 활동을 스스로 확인하 면서 이완이나 긴장 상태를 조절하도록 훈련할 수 있다.

\section{암 환자에서의 약물치료}

암 환자에서 불면증의 약물치료는 일반인에서의 약물치료 와 크게 차이가 나지는 않는다. 다만 환자의 내과적 상태나 현재 복용 중인 약물, 현재 시행하고 있는 암 관련 치료들과 의 상호작용들을 고려하여야 한다. 또한 불면증을 유발할 만 한 기저질환 및 정신과적 스트레스 등을 고려하고 이에 대한 적절한 처치를 하는 것이 우선되어야 한다. 따라서 암 환자 의 불면증에 대한 약물치료는, 불면증 자체를 해결하는 방법 과 불면증을 유발할 만한 상황을 약물로 해결하는 방법 두 가지로 나누어 생각을 해야 한다.

불면증에 대한 약물치료

일반적으로 불면증 치료로 사용되는 약물은 크게 1) 벤조 디아제핀, 2) Z-drug, 3) 항히스타민 효과와 관련된 약제들, 
Table 4. Drugs used for insomnia in South Korea

\begin{tabular}{|c|c|}
\hline Drugs & Most common dosage (mg) \\
\hline \multicolumn{2}{|l|}{ Benzodiazepines } \\
\hline Flurazepam* & $15-30$ \\
\hline Triazolam* & $0.125-0.25$ \\
\hline Flunitrazepam* & 1 \\
\hline Brotizolam* & 0.25 \\
\hline Clonazepam & 0.5 \\
\hline \multicolumn{2}{|l|}{ Non-benzodiazepine } \\
\hline \multicolumn{2}{|c|}{ Non-benzodiazepine GABA modulator (z-class) } \\
\hline Zolpidem immediate-release* & $5-10$ \\
\hline Zolpidem controlled-release* & $6.25-12.5$ \\
\hline Eszopiclone* & $1-3$ \\
\hline \multicolumn{2}{|l|}{ Antidepressants } \\
\hline Trazodone & $25-50$ \\
\hline Mirtazapine & $7.5-30$ \\
\hline Amitriptyline & $10-30$ \\
\hline Doxepin* & $3-6$ \\
\hline \multicolumn{2}{|l|}{ Antihistamines } \\
\hline Doxylamine* & 25 \\
\hline Diphenhydramine* & $25-50$ \\
\hline \multicolumn{2}{|l|}{ Melatonin } \\
\hline Prolonged-release melatonin* & 2 \\
\hline \multicolumn{2}{|l|}{ Antipsychotics } \\
\hline Quetiapine & $25-50$ \\
\hline Olanzapine & $2.5-5$ \\
\hline
\end{tabular}

*approved by Korean Food and Drug Administration. GABA: $\gamma$ aminobutyric acid

4) 멜라토닌 등으로 크게 나눠볼 수 있다(Table 4).

암 환자는 암의 병기와 시행 중인 치료에 따라 신체 상태가 매우 다르기 때문에, 벤조디아제핀이나 Z-drug 처방 시 환자 의 의식 상태 및 신체적 상태에 대해 면밀하게 평가해야 한 다. 또한 부가적으로 복용하는 약물도 다양하기 때문에 상호 작용도 고려해야 한다. 일례로, 통증 조절을 위해 마약성 진 통제를 복용하고 있다면 마약성 진통제의 부작용 때문에 낮 동안 멍하고 졸리운 경우가 많다. 이 경우에는 벤조디아제핀 계열의 약물을 피하는 것이 좋다.

암 환자의 불면증에 대해 잠을 쉽게 잘 들지 못하는 수면 개시장애인지, 잠을 잘 유지하지 못하는 수면유지장애인지 를 구분하는 것이 필요하다. 수면개시장애인 경우 벤조디아 제핀이나 Z-drug을 사용해 볼 수 있고, 국내에는 아직 들어 와 있지 않지만 멜라토닌 수용체 작용제인 ramelteon 등을 사 용해 볼 수 있다. 수면유지장애인 경우는 Z-drug이나, doxepine과 trazodone과 같은 항히스타민 효과를 갖는 항우울
제들을 사용해 볼 수 있고, 55세 이상 환자들에게서는 melatonin 지속형 방출제를 적용해 볼 수 있다. 아직 국내에는 들 어와 있지 않지만 orexin 수용체 길항제인 suvorexant도 사 용해 볼 수 있다.

수면제를 복용하는 시간을 정해 주는 것도 매우 중요하다. 일반적으로 수면제는 자기 30분 전에 복용하는 것으로 지침 을 주고 있다. 그러나 불면증을 호소하는 환자들은 일찍 잠 이 들기 위하여 일찍 누워서 수면제를 일찍 복용하는 경향이 있는데, ${ }^{29}$ 이는 수면제에 대한 만족도를 저하시켜 결과적으 로 수면제의 용량을 늘리는 상황을 만들게 된다. 특히 복용 중인 수면제에 만족하는 암 환자들은 그렇지 않은 환자들에 비해 수면제를 늦게 복용하고 아침에 일찍 일어나는 경향이 있다. ${ }^{27}$ 또한 하루 중 총 침상 시간(TIB/d)이 긴 경우 수면제 에 대한 만족도가 저하되기 때문에 환자의 불면증을 평가하 고 수면제를 처방할 경우 수면제 복용 시간에 대하여 환자와 상의를 하는 것이 중요하다. ${ }^{27}$

불면증을 유발할 만한 기저질환에 대한 약물치료

불면증의 만성화 과정을 설명하는 3-P 모델에서 유발 요 인(precipitating factor)은 불면증 발생에 중요한 역할을 한 다. 암을 진단받고 치료하는 도중 발생하는 스트레스, 우울 증 및 불안증, 신체적 통증과 피로감, 폐경 후 증상, 수술을 받고 입원해 있는 상황 자체, 항암치료와 방사선 치료 등 매 우 다양한 상황들이 유발 요인으로 작용한다. 암 환자를 주로 진료하지 않는 수면 전문가 입장에서 이 문제들을 해결하는 데에는 한계가 있는 것은 사실이나, 암 환자의 불면증을 이해 하고 해결하는 데 고려해야 할 중요한 일임에는 틀림없다.

정신과적 증상들 중 환자의 불안감을 줄이기 위하여 벤조 디아제핀 계열 항불안제를 사용할 수 있다. 환자의 우울증 해결을 위해서는 항우울제를 주로 사용하는데, doxepine이 나 trazodone과 같은 삼환계 항우울제는 고용량을 사용할 경 우에 항우울제로서 역할을 하지만 심한 졸림증과 구갈, 심박 동에 영향을 줄 수 있어 최근에는 항우울제로는 잘 사용하지 않는다. 대신 선택적 세로토닌 재흡수 차단제(selective serotonin reuptake inhibitor, SSRI)를 위시한 최신의 항우울제 들을 사용하는 경향이 있다.

암 환자들은 심한 통증 때문에 잠을 잘 못 자는 경우도 많 은데, ${ }^{35}$ 통증 조절을 위하여 마약성 진통제를 사용하다 보면 낮 동안 졸림 증상이 유발된다. 그러다 보면 결국 밤에는 못 자고 낮에 자는 등 일주기리듬에 문제가 발생한다. 이때 벤 조디아제핀 계열의 수면제를 사용해도 통증 때문에 수면 효 과가 잘 나타나지 않고 결국 낮 동안 졸림 증상만 가중될 수 있다. 따라서 통증 조절을 우선적으로 실시해야 하고, 벤조 
디아제핀보다는 doxepine이나 trazodone과 같은 삼환계 항 우울제가 통증 조절에도 유리할 수 있다. ${ }^{36}$

유방암 환자는 에스트로젠 수용체 양성인 경우 tamoxifen 을 복용하게 되는데, ${ }^{37}$ tamoxifen은 선택적 에스트로젠 수용 체 조절제(selective estrogen-receptor modulator)로 여성 호 르몬을 억제하여 야간의 발한 및 열감 등을 유발한다. 따라서 tamoxifen을 복용하는 환자들은 부작용으로 잠을 들기가 어 렵고, 잠이 들어도 자주 깨는 증상을 호소한다. 비단 tamoxifen을 복용한 유방암 환자뿐 아니라, 양쪽 난소를 제거하게 되는 난소암 환자나, 일부 항암제들 역시 발한 및 열감을 유 발한다..$^{38}$ 이 경우 선택적 세로토닌 재흡수 차단제(SSRI)나 선택적 세로토닌 노르에피네프린 재흡수 차단제(SNRI)와 같은 약물을 사용해 볼 수 있다. 다만 tamoxifen이 체내 대사 과정에서 cytochrome p450 2D6에 영향을 받기 때문에 상호 작용이 없는 venlafaxine을 1 차적으로 사용한다. 39,40

암 환자의 병기를 평가하는 것도 중요한데, 원발암에서 외 부 장기로의 전이 정도에 따라 통증과 신체적 불편감, 심리 적 스트레스 등 여러 가지 상황이 변하기 때문이다. 척추로 전이되는 경우에는 똑바로 누워서 잠을 자기가 어렵다. 마약 성 진통제로 통증을 조절하더라도 잠을 자는 체위가 불편감 을 유발하고 체위 변경이 어려워 잠을 자다가 깨는 경우가 잦다. 뇌 전이가 있는 경우 섬망이나 인지기능장애가 발생할 수 있고 이로 인하여 불면증이 유발되는 경우가 있다. 이 경 우, 통상적으로 사용하는 벤조디아제핀이나 Z-drug이 오히 려 증상을 악화시킬 여지가 있고, trazodone과 doxepine과 같은 약물은 섬망 환자의 행동 조절에 대한 효과가 크지 않 아, quetiapine과 같은 항정신병 약물이 오히려 섬망 증상을 줄이고 불면증을 호전시키는 데 효과적으로 사용될 수 있다.

\section{불면증의 양상을 나타낼 수 있는 다양한 수면장애들}

\section{일주기리듬 수면각성장애(circadian rhythm sleep- wake disorder)}

암 환자가 피로감으로 인해 낮 동안 오래 누워 있다 보면 야간의 수면에 문제가 발생한다. 일종의 일주기리듬 수면각 성장애로도 볼 수 있지만, 진단적으로는 구분이 필요하다. 일주기리듬 수면각성장애는 수면-각성 주기가 앞으로 당겨 져 일찍 잠을 자고 일찍 일어나거나(advanced type), 수면각성 주기가 뒤로 늦춰져 늦게 잠을 자고 늦게 일어나는 경 우(delayed type) 등으로 구분된다. 그런데 수면-각성 주기 에 문제는 있으나, 그 시간 동안에는 수면을 잘 취하는 것이 보통이다. 암 환자들은 낮 동안 피로감으로 누워 있지만 잠 이 드는 것이 아니라 그냥 누워만 있는 경우가 흔하다. 따라
서 진단적으로 일주기리듬 수면각성장애로 진단하기 애매한 경우가 있으나, 그럼에도 불구하고 일주기리듬 수면각성장 애의 개념을 파악하는 것은 암 환자의 불면증과 낮 동안의 피로감과의 관계를 파악하는 데 도움이 된다. 만약 일주기리 듬 수면각성장애로 진단하는 데 무리가 없다면 통상적인 방 법에 따라 광치료와 멜라토닌을 사용하여 수면-각성 주기를 정상화시킬 수 있다.

역으로 만성적인 일주기리듬의 장애가 암 발생에 영향을 주기도 한다. ${ }^{41}$ 세계보건기구의 International Agency for Research on Cancer는 2007년 교대근무가 암을 유발할 가능 성이 있다(group 2A)고 규정하였는데 2011년의 추적관찰 보 고서에서 야간 교대근무를 암 위험인자로 보고했다. ${ }^{42,43}$ 멜라 토닌은 인체에서 일종의 항암인자로 작용하는데, ${ }^{44}$ 일주기리 듬의 장애로 인해 멜라토닌 농도에 변화가 생기는 것과 유방 암과의 연관관계가 보고되고 있다. ${ }^{45}$ 특히 야간 교대근무를 하는 여성에게서 유방암 위험도가 증가한다는 연구 결과가 있고 메타연구에서도 동일한 연관성이 보고된 바 있다. ${ }^{46} \mathrm{NK}$ 세포의 감소, ${ }^{47}$ 멜라토닌 농도 감소로 인한 IL-2, IL-6의 감 소, ${ }^{48}$ 활성산소종(reactive oxygen species)의 증가, 에스트로 젠 수용체에 길항제로 작용하는 멜라토닌 농도의 감소 등이 기전으로 거론되고 있다. ${ }^{49}$

\section{수면 관련 호흡장애(sleep-related breathing disorder)}

폐쇄성 수면무호흡증은 잠을 자는 동안 호흡이 멈추거나 얕아지는 것을 주 증상으로 하는 질환으로, 밤에 잠을 자는 동안 근육 긴장도가 감소하고 흡기 시 상기도에 음압이 걸리 면서 쉽게 폐쇄가 일어나게 된다. 산소포화도가 저하되고 쉽 게 각성이 되어 자주 깨게 되다 보니 밤 동안 숙면을 못 취하 고 낮에 졸림증이 발생하며 사고 위험성이 높아지기도 한다. 수면 관련 호흡장애와 암 발생과의 연관성에 대해서도 연구 가 이뤄지고 있는데, 야간의 지속된 저산소증이 암 발생의 위 험인자가 될 수 있다는 연구가 있다. ${ }^{50}$ 물론 이에 대한 반론도 있으며, ${ }^{51}$ 이 관계가 모든 암종에서 관찰된다기보다는 특정 암종에서만 관찰된다는 주장도 있다..$^{2}$ 반복된 저산소증이 활 성산소종을 증가시키고, hypoxia induced factor-1을 통해 $\mathrm{p} 53$ 의 활성화에 역할을 하며, ${ }^{53}$ 종양의 성장과 전이를 촉진한 다고 알려져 있다. ${ }^{54}$ 이 부분에 대해서는 아직은 연구가 더 필 요한 실정이다. 다만 임상에서는 두경부암 환자에서 폐쇄성 수면무호흡증의 발생률이 높다는 것은 잘 알려져 있다.55

\section{하지불안증후군 및 주기성 사지운동장애}

하지불안증후군은 환자가 잠을 잘 이루기 어렵다는 호소 를 주로 하기 때문에 수면개시장애를 평가할 때 감별해야 하 
는 질환이다. 경우에 따라서는 중간에 자다가 깨는 경우도 흔하기 때문에 수면유지장애 진단 시에도 감별을 요한다. 하 지불안증후군은 다리에 불편하고 불쾌한 느낌으로 인해 다 리를 움직이고 싶은 충동이 생겨 잠을 잘 이루지 못하는 질환 이다. 주로 밤에 잘 나타나며 낮에도 누워 있거나 쉴 경우에 발생할 수도 있다. 암 환자에서 하지불안증후군의 유병률이 높은 편이며 항암 치료 이후 발생한 항암제에 의한 말초신경 병증(chemotherapy induced peripheral neuropathy)과 감별 을 요한다. ${ }^{56}$ 암 환자에서는 빈혈이 흔하면서 중요한 문제이 기 때문에 암 환자에서 하지불안증후군을 평가할 시 반드시 빈혈에 대한 평가를 하는 것이 좋다. ${ }^{7}$

\section{기면병 및 특발성 과다수면증}

기면병은 낮졸림증과 탈력발작, 수면마비와 입면 시 환각 을 주 증상으로 하는 질환으로 심한 낮졸림증 호소 시 반드 시 감별해야 하는 질환이다. 주로 각성을 유지하게 해 주는 신경펩타이드인 orexin/hypocretin 농도 감소와 연관이 있다. 야간 수면다원검사와 함께 주간에 수면잠복기반복검사를 시 행하여 평균 수면잠복기 8분 이내, sleep-onset rapid eye movement periods 2 회 이상 관찰 시 진단이 내려진다. 특발 성 과수면증은 낮졸림증은 심하나 기면병의 진단 기준을 충 족하지 못하는 경우 진단이 내려진다. 기면병 환자에서 암 발 생 위험도가 증가한다는 보고가 있는데 뇌종양에서 기면병 및 과수면증의 유병률이 높고, ${ }^{58,59}$ paraneoplastic syndrome 과의 연관성도 제기되었다. ${ }^{60}$

\section{결 론}

암 환자의 불면증 및 수면장애는 환자의 삶의 질을 저하시 키는 불편하면서도 흔한 증상임에도 불구하고, 아직까지는 임상가의 관심을 상대적으로 덜 받고 있는 증상이다. 불면증 은 적절한 진단과 치료를 통하여 충분히 개선 가능한 증상이 지만, 원인에 대한 파악이나 올바른 수면 습관에 대한 교육 없이 무분별하게 수면제를 사용하다 보면 의존 및 남용의 문 제가 발생한다. 이는 암 환자에게서도 다르지 않을 뿐 아니 라, 동반된 질환이나 투약하는 약물이 횔씬 더 많은 암 환자 에게서는 더욱더 중요한 문제라 할 수 있다. 따라서 임상에 서 암 환자에게 수면제를 처방하기 전 불면증의 원인을 파악 하고 해결하기 위한 노력이 선행되어야 하며, 올바른 수면 습관에 대한 교육 또한 미리 이뤄지는 것이 필요하다. 암 환 자에게 특화된 인지행동치료 기법의 개발과 함께 암 환자에 게 좀 더 안전하게 수면제를 처방할 수 있는 기법들을 개발 하는 일이 수면 전문가에게 주어진 과제가 되겠다. 또한 다
양한 일차성 수면장애들이 암 환자에서 어떻게 발현되는지, 암과는 어떠한 연관성을 갖고 있는지를 파악하여 환자의 수 면장애를 해결하는 일 역시 아직까지는 임상에서 잘 이뤄지 지 않고 있는 분야이다. 본 논문에서 논의된 여러 사항들이 암 환자의 불면증 및 수면장애를 진단하고 해결하는 시스템 을 활성화하는 데 도움이 되기를 기대한다.

\section{Acknowledgments}

\section{None.}

\section{Conflicts of Interest}

The author has no potential conflicts of interest to disclose.

\section{ORCID iD}

Seockhoon Chung https://orcid.org/0000-0002-9798-3642

\section{REFERENCES}

1. Zabora J, BrintzenhofeSzoc K, Curbow B, Hooker C, Piantadosi S. The prevalence of psychological distress by cancer site. Psychooncology 2001; 10:19-28.

2. Steel JL, Geller DA, Gamblin TC, Olek MC, Carr BI. Depression, immunity, and survival in patients with hepatobiliary carcinoma. J Clin Oncol 2007;25:2397-2405.

3. Franzen PL, Buysse DJ. Sleep disturbances and depression: risk relationships for subsequent depression and therapeutic implications. Dialogues Clin Neurosci 2008;10:473-481.

4. American Academy of Sleep Medicine. The international classification of sleep disorders. 3rd ed. Westchester: AASM, 2001.

5. Savard J, Morin CM. Insomnia in the context of cancer: a review of a neglected problem. J Clin Oncol 2001;19:895-908.

6. Palesh OG, Roscoe JA, Mustian KM, et al. Prevalence, demographics, and psychological associations of sleep disruption in patients with cancer: University of Rochester Cancer Center-Community Clinical Oncology Program. J Clin Oncol 2010;28:292-298.

7. Park B, Youn S, Hann CWC, et al. Prevalence of insomnia among patients with the ten most common cancers in South Korea: health insurance review and assessment service-national patient sample. Sleep Med Res 2016;7:48-54.

8. Berger AM, Wielgus K, Hertzog M, Fischer P, Farr L. Patterns of circadian activity rhythms and their relationships with fatigue and anxiety/ depression in women treated with breast cancer adjuvant chemotherapy. Support Care Cancer 2010;18:105-114.

9. Chung S. Korean clinical practice guideline for management of insomnia in adults. Seoul: Korean Neuropsychiatric Association, 2019.

10. Garland SN, Johnson JA, Savard J, et al. Sleeping well with cancer: a systematic review of cognitive behavioral therapy for insomnia in cancer patients. Neuropsychiatr Dis Treat 2014;10:1113-1124.

11. Ong J, Suh S. Utilizing cognitive-behavioral therapy for insomnia to facilitate discontinuation of sleep medication in chronic insomnia patients. Sleep Med Res 2012;3:1-6.

12. Perlis ML, Jungquist C, Smith MT, Posner D (Trans. Kim JH, Seo SY, Yoon $\mathrm{CH}$ ). Cognitive behavioral treatment of insomnia: a session-by-session guide. Paju: Koonja, 2013.

13. Jacobs GD (Trans. Lee C, Hong JP). Say good night to insomnia: the six-week, drug-free program developed at Harvard medical school. Seoul: KIOM, 2004.

14. Korean Society of Sleep Medicine. Cognitive behavioral treatment guidebook of insomnia. Seoul: Korean Society of Sleep Medicine, 2017.

15. Morin CM. Cognitive-behavioral approaches to the treatment of insomnia. J Clin Psychiatry 2004;65 Suppl 16:33-40. 
16. Borbély AA. A two process model of sleep regulation. Hum Neurobiol 1982;1:195-204

17. Parker KP, Bliwise DL, Ribeiro M, et al. Sleep/wake patterns of individuals with advanced cancer measured by ambulatory polysomnography. J Clin Oncol 2008;26:2464-2472.

18. Bartsch C, Bartsch H, Bellmann O, Lippert TH. Depression of serum melatonin in patients with primary breast cancer is not due to an increased peripheral metabolism. Cancer 1991;67:1681-1684.

19. Berger AM, Farr LA, Kuhn BR, Fischer P, Agrawal S. Values of sleep/ wake, activity/rest, circadian rhythms, and fatigue prior to adjuvant breast cancer chemotherapy. J Pain Symptom Manage 2007;33:398-409.

20. Youn S, Choi B, Yi K, Chung S. Cognitive-behavioral therapy for insomnia for cancer patients. Korean J Psycho-Oncol 2017;3:1-10.

21. Zhou ES, Suh S, Youn S, Chung S. Adapting cognitive-behavior therapy for insomnia in cancer patients. Sleep Med Res 2017;8:51-61.

22. Spielman AJ, Caruso LS, Glovinsky PB. A behavioral perspective on insomnia treatment. Psychiatr Clin North Am 1987;10:541-553.

23. Rumble ME, Keefe FJ, Edinger JD, Affleck G, Marcom PK, Shaw HS. Contribution of cancer symptoms, dysfunctional sleep related thoughts, and sleep inhibitory behaviors to the insomnia process in breast cancer survivors: a daily process analysis. Sleep 2010;33:1501-1509.

24. Runowicz CD, Leach CR, Henry NL, et al. American Cancer Society/ American Society of Clinical Oncology breast cancer survivorship care guideline. J Clin Oncol 2016;34:611-635.

25. Graydon JE, Bubela N, Irvine D, Vincent L. Fatigue-reducing strategies used by patients receiving treatment for cancer. Cancer Nurs 1995;18: 23-28.

26. Matthews EE, Janssen DW, Djalilova DM, Berger AM. Effects of exercise on sleep in women with breast cancer: a systematic review. Sleep Med Clin 2018;13:395-417.

27. Youn S, Choi B, Lee S, Kim C, Chung S. Time to take sleeping pills and subjective satisfaction among cancer patients. Psychiatry Investig 2020; 17:249-255.

28. Andrew BN, Guan NC, Jaafar NRN. The use of methylphenidate for physical and psychological symptoms in cancer patients: a review. Curr Drug Targets 2018;19:877-887.

29. Chung S, Youn S, Yi K, Park B, Lee S. Sleeping pill administration time and patient subjective satisfaction. J Clin Sleep Med 2016;12:57-62.

30. Chung S, Youn S, Choi B. Assessment of cancer-related dysfunctional beliefs about sleep for evaluating sleep disturbance in cancer patients. Sleep Med Res 2017;8:98-101.

31. Mortezaee K, Potes Y, Mirtavoos-Mahyari H, et al. Boosting immune system against cancer by melatonin: a mechanistic viewpoint. Life Sci 2019;238:116960.

32. Jiao L, Duan Z, Sangi-Haghpeykar H, Hale L, White DL, El-Serag HB. Sleep duration and incidence of colorectal cancer in postmenopausal women. Br J Cancer 2013;108:213-221.

33. Reiche EM, Nunes SO, Morimoto HK. Stress, depression, the immune system, and cancer. Lancet Oncol 2004;5:617-625.

34. Nooner AK, Dwyer K, DeShea L, Yeo TP. Using relaxation and guided imagery to address pain, fatigue, and sleep disturbances: a pilot study. Clin J Oncol Nurs 2016;20:547-552.

35. Pachman DR, Barton DL, Swetz KM, Loprinzi CL. Troublesome symptoms in cancer survivors: fatigue, insomnia, neuropathy, and pain. $J$ Clin Oncol 2012;30:3687-3696.

36. Mika J, Zychowska M, Makuch W, Rojewska E, Przewlocka B. Neuronal and immunological basis of action of antidepressants in chronic painclinical and experimental studies. Pharmacol Rep 2013;65:1611-1621.

37. Jameera Begam A, Jubie S, Nanjan MJ. Estrogen receptor agonists/antagonists in breast cancer therapy: a critical review. Bioorg Chem 2017; 71:257-274.

38. Marino JL, McNamara HC, Hickey M. Managing menopausal symptoms after cancer: an evidence-based approach for primary care. Med J Aust 2018;208:127-132.

39. Chan CWH, Law BMH, So WKW, Chow KM, Waye MMY. Pharma- cogenomics of breast cancer: highlighting CYP2D6 and tamoxifen. $J$ Cancer Res Clin Oncol 2020;146:1395-1404.

40. Ramaswami R, Villarreal MD, Pitta DM, Carpenter JS, Stebbing J, Kalesan B. Venlafaxine in management of hot flashes in women with breast cancer: a systematic review and meta-analysis. Breast Cancer Res Treat 2015;152:231-237.

41. Samuelsson LB, Bovbjerg DH, Roecklein KA, Hall MH. Sleep and circadian disruption and incident breast cancer risk: an evidence-based and theoretical review. Neurosci Biobehav Rev 2018;84:35-48.

42. Straif K, Baan R, Grosse Y, et al. Carcinogenicity of shift-work, painting, and fire-fighting. Lancet Oncol 2007;8:1065-1066.

43. Stevens RG, Hansen J, Costa G, et al. Considerations of circadian impact for defining 'shift work' in cancer studies: IARC Working Group report. Occup Environ Med 2011;68:154-162.

44. Blask DE. Melatonin, sleep disturbance and cancer risk. Sleep Med Rev 2009;13:257-264.

45. Ward EM, Germolec D, Kogevinas M, et al.; IARC Monographs Vol 124 Group. Carcinogenicity of night shift work. Lancet Oncol 2019;20:10581059.

46. Lin X, Chen W, Wei F, Ying M, Wei W, Xie X. Night-shift work increases morbidity of breast cancer and all-cause mortality: a meta-analysis of 16 prospective cohort studies. Sleep Med 2015;16:1381-1387.

47. Born J, Lange T, Hansen K, Mölle M, Fehm HL. Effects of sleep and circadian rhythm on human circulating immune cells. J Immunol 1997; 158:4454-4464.

48. García-Mauriño S, Pozo D, Calvo JR, Guerrero JM. Correlation between nuclear melatonin receptor expression and enhanced cytokine production in human lymphocytic and monocytic cell lines. J Pineal Res 2000;29:129-137.

49. Cos S, González A, Martínez-Campa C, Mediavilla MD, AlonsoGonzález C, Sánchez-Barceló EJ. Estrogen-signaling pathway: a link between breast cancer and melatonin oncostatic actions. Cancer Detect Prev 2006;30:118-128.

50. Campos-Rodriguez F, Martinez-Garcia MA, Martinez M, et al. Association between obstructive sleep apnea and cancer incidence in a large multicenter Spanish cohort. Am J Respir Crit Care Med 2013;187:99105.

51. Kendzerska T, Leung RS, Hawker G, Tomlinson G, Gershon AS. Obstructive sleep apnea and the prevalence and incidence of cancer. $C M A J$ 2014;186:985-992.

52. Gozal D, Ham SA, Mokhlesi B. Sleep apnea and cancer: analysis of a nationwide population sample. Sleep 2016;39:1493-1500.

53. Wang P, Guan D, Zhang XP, Liu F, Wang W. Modeling the regulation of p53 activation by HIF-1 upon hypoxia. FEBS Lett 2019;593:2596-2611.

54. Yttersian Sletta K, Tveitarås MK, Lu N, et al. Oxygen-dependent regulation of tumor growth and metastasis in human breast cancer xenografts. PLoS One 2017;12:e0183254.

55. Friedman M, Landsberg R, Pryor S, Syed Z, Ibrahim H, Caldarelli DD. The occurrence of sleep-disordered breathing among patients with head and neck cancer. Laryngoscope 2001;111:1917-1919.

56. Ostacoli L, Saini A, Ferini-Strambi L, et al. Restless legs syndrome and its relationship with anxiety, depression, and quality of life in cancer patients undergoing chemotherapy. Qual Life Res 2010;19:531-537.

57. Aapro M, Beguin Y, Bokemeyer C, et al. Management of anaemia and iron deficiency in patients with cancer: ESMO clinical practice guidelines. Ann Oncol 2018;29:iv96-iv110.

58. Tseng CM, Chen YT, Tao CW, et al. Adult narcoleptic patients have increased risk of cancer: a nationwide population-based study. Cancer Epidemiol 2015;39:793-797.

59. Khan RB, Merchant TE, Sadighi ZS, et al. Prevalence, risk factors, and response to treatment for hypersomnia of central origin in survivors of childhood brain tumors. J Neurooncol 2018;136:379-384.

60. Landolfi JC, Nadkarni M. Paraneoplastic limbic encephalitis and possible narcolepsy in a patient with testicular cancer: case study. Neuro Oncol 2003;5:214-216. 